\title{
A SEJTCIKLUS HATÁSA A BK CSATORNA FENOTÍPUSÁRA GLIOBLASZTÓMA SEJTEKEN
}

\author{
Szerző: \\ Fehér Ádám \\ Debreceni Egyetem
}

Szerző e-mail címe:

feheradam5@citromail.hu

\section{Lektorok:}

Varga Zoltán (Dr.)

Debreceni Egyetem

Szántó G. Tibor (Dr.)

Debreceni Egyetem

...és további két anonim lektor

\begin{abstract}
Absztrakt
A glioblasztóma egy gyakori malignus agydaganat, mely inváziójához hozzájárul a BK csatorna. Célunk volt kideríteni a BK béta alegységek kifejeződését a specifikus csatornagátlás érdekében. Az U-87 MG sejtvonalat használtuk, melynek szinkronizációja után vizsgáltuk biofizikai paramétereit és BK béta alegységeit patch-clamppel. Eredmény: az M fázisú sejtek jelentős eltérést mutattak, melyet a béta alegység kifejeződésének eltérése nem magyaráz, ami egy ismeretlen ioncsatorna aktivitására utal.
\end{abstract}

Kulcsszavak: glioblasztóma, BK csatorna, sejtciklus, járulékos alegység

Diszciplina: orvostudomány

\section{Abstarct \\ THE EFFECT OF THE CELL CYCLE ON THE PHENOTYPE \\ OF THE BK CHANNEL IN GLIOBLASTOMA CELLS}

The glioblastoma is a common malignant brain tumor, which invasivity is caused by the BK channel. We aimed to find out the expression of the BK beta subunits to achieve the specific inhibition of the BK channel. We used the U-87 MG cell line. After synchronisation we studied the biophysical parameters of the cells and the expression of the BK beta subunits with patch-clamp. Results: the M phase cells shown significant differences, but it's not associated with the differences in the beta subunits.

Keywords: glioblastoma, BK channel, cell cycle, auxillary subunit

Discipline: medicine

Fehér Ádám (2020): A sejtciklus hatása a BK csatorna fenotípusára glioblasztóma sejteken. OxIPO - interdiszciplináris tudományos folyóirat, 2020/1, 9-22.

doi: 10.35405/OXIPO.2020.1.9 
A gliómák az agyállomány gliasejtjeiből álló tumorok, melynek fő csoportjai közé tartoznak az oligodendrogliomák, ependymomák és az astrocytomák. Az utóbbinak az egyik leggyakoribb formája a diffúz astrocytoma, mely a felnőttkori primer gliómák 80\%-át képezi. Szövettani megjelenés alapján a glioblasztóma a legkevésbé differenciált (IV. grádusú) diffúz astrocytoma, melynek kialakulásában számos jelátviteli útvonalat érintő mutáció fedezhető fel, köztük a p53 és Rb tumorszupresszor gének funkcióvesztő, valamint a PI3K funkciónyerő mutációja (Kumar és tsai, 2007).

A hisztológialag igazolt glioblasztóma prognózisa rendkívül kedvezőtlen, az átlagos túlélési idő a legjobb kezelések ellenére sem haladja meg a 15 hónapot (Burzynski és tsai, 2004). A tumorsejtek invazív tulajdonságát már sokan vizsgálták és számos cikk szól arról, hogy mik okozhatják a glioblasztómának ezt a malignus tulajdonságát. Leggyakrabban az ioncsatornák, köztük a feszültség-függő klorid (ClC-3 - lásd: Wang és tsai, 2017), kálium (BK - lásd: Rosa és tsai, 2017) és nátrium csatornák (Nav1.7 - lásd: Joshi és tsai, 2011) szerepe merül fel.

Azt, hogy a BK csatornának köze van-e a glioblasztóma invazivitásához Steinle és tsai (2011) vizsgálták migrációs esszével és arra jutottak, hogy az ionizáló sugárzás hatására megemelkedett migrációs készséget az egyidejűleg alkalmazott specifikus gátlószer, a paxilline, jelentősen, a kontroll (besugárzatlan) szint alá csökkenti. A BK csatorna és a glioblasztóma invazivitása közötti összefüggésre a jelenlegi elmélet a következő:

A BK csatornával paralel aktiválódnak a storage-operated CRAC csatornák, ami megnöveli az intracelluláris kalcium szintet, így a CAMKII aktív lesz és foszforilálja a CLC-3 antiportert, ami azt jelenti, hogy a kifele irányuló káliumáram hatására meg fog jelenni egy szintén kifele irányuló klorid áram (Huber és tsai, 2013). Ennek a következménye lesz a víz kiáramlása a sejtből, így a sejt zsugorodik, ami miatt képes lesz beszűrni az agyállományt (McFerin és Sontheimer, 2006).

A BK csatorna egy nagy konduktanciájú (200-300 pS 150 mM KCL-ban) feszültség- és kalcium-függő kálium csatorna, mely a legtöbb emberi szövetben jelen van. A csatorna alfa alegysége a transzmembrán modifikáló S0 hélix és az intracelluláris $\mathrm{Ca}^{2+}$ szenzor $\mathrm{RCK}$ domének kivételével hasonlít a többi feszültség-függő kálium csatorna alfa alegységéhez. Négy alfa alegység alkot egy homotetramert és minden alfához társulhat egy járulékos béta alegység. A béta alegységek a csatorna finomhangolói, mivel módosítják a csatorna kinetikáját és feszültség-függését (Lee és Cui, 2010; Li és Yan, 2016).

Ezen kívül fontos megjegyezni, hogy a bétáknak mind a farmakológiai tulajdonságaik, mind a szöveti megoszlásuk eltér (Poulsen és tsai, 2009).

Emiatt ha ismernénk a glioblasztóma BK béta alegységének kifejeződését és annak sejtciklus-függését, akkor akár ki lehetne fejleszteni egy specifikus, szövet- 
mintázat-függő gátlószert, ami a paxilinne-el ellentétben nem okozna halálos mellékhatásokat.

\section{MÓDSZER}

\section{Minta}

Az U-87 MG glioblasztóma sejtvonalat használtuk, ami a legelterjedtebb sejtvonal a glioblasztóma kutatásában. A rövidítés jelentése: Uppsala-87 Malignant Glioma. A sejtvonalat képező eredeti sejtek egy 44 éves férfi páciensből lettek biopsziával eltávolítva 1966-ban. A sejtek morfológiája epithel, genotípusukat pedig egy közel diploid, hypodiploiditás jellemzi. Habár a közel 50 évben számos mutáció bekövetkezett (Allen és tsai, 2016), nincs semmilyen bizonyíték arra, hogy az invazivitásban is lenne eltérés az U-87 sejtek és a glioblasztóma között.
A kísérlethez ezeket a sejteket szinkronizáltuk a sejtciklus különböző fázisaiba, mint G0/G1, $M$ és $S$ fázis. A három szinkronizált populáció mellett (G0/G1, M, S) hagytunk egy szinkronizálatlan csoportot kontrollnak. A szinkronizáció után az sejtek elektrofiziológiai paramétereit vizsgáltuk patch-clamp technológiával, ahol a mintavételezés is zajlott ( $\mathrm{n}=10$ sejt minden csoportból a biofizika paraméterek felméréséhez és szintén $n=10$ sejt minden populációból a BK béta expresszió meghatározásához). Fontos említeni, hogy az elérhető legjobb szinkronizálási módszer ellenére sem számíthatunk 100\%-os sikerarányra, de a szinkronizálással jelentősen nő a sejtek száma az adott sejtciklus fázisában (lásd: 1. táblázat). Így nagyobb valószínűséggel tudunk találni az adott fázisra jellemző morfológiájú és méretű sejteket (Lloyd és tsai, 2000).

1. táblázat: A sejtszinkeronizálás sikeressége (forrás: a Szurzố)

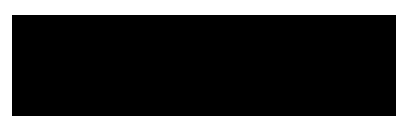

\section{G0/G1 fázis}

\section{S fázis}

M fázis

\begin{tabular}{|l|c|c|c|}
\hline Kontroll & $82,7 \%$ & $7,4 \%$ & $9,8 \%$ \\
\hline Kolhicin & $58 \%$ & $8,6 \%$ & $33,4 \%$ \\
\hline Éheztetés & $90,8 \%$ & $5,4 \%$ & $3,8 \%$ \\
\hline Aphidicolin & $69,6 \%$ & $16,8 \%$ & $13,6 \%$ \\
\hline
\end{tabular}




\section{Eszközök}

\section{Sejtszinkronizálás}

Ez a labortechnika az adott sejtciklus fázisban lévő sejtek arányának megemelésére szolgál. Számos módja van a sejtszinkronizálásnak, de csak azokra térünk ki, melyeket használtunk a kutatásunk során.

A G0/G1 fázis eléréséhez éheztetéses technikát alkalmaztunk (szérummentes DMEM = Dulbecco's Modified Eagle Medium). Szérum nélkül a sejtek nem jutnak növekedési faktorokhoz, melyek szükségesek a sejtproliferációs jelátviteli útvonalak aktiválásához. Nélkülük a sejtek a G0/G1 fázisban maradnak (Yan és Tao, 2007). Az M fázisba szinkronizáláshoz kolhicint adtunk a médiumhoz, ami meggátolja a mikrotubulusok polimerizációját, így a sejtciklus megáll az $\mathrm{M}$ fázisnak a metafázisában (Taylor, 1965). Az S fázisú sejtek arányának megnöveléséhez pedig aphidicolint alkalmaztunk. Ez a szer specifikusan gátolja a DNS polimeráz alfát, így gátolva a DNS replikációt (lásd:
Darzynkiewicz és tsai, 2011). Saját protokollokat használtunk a szinkronizáláshoz a hatásos koncentrációk ismeretében (v.ö.: Tate és Ferringo, 2005).

\section{Áramlási citometria}

Ez a technika a sejtek differenciációjához szükséges, mely megtörténhet különböző attribútumok alapján (pl. sejtméret $=$ előre szórás/granuláltság = oldalra szórás; lásd: 1. ábra). Továbbá megjelölhetjük a sejtkomponenseket fluoreszcens festékkel és detektálhatjuk az emmitált fényt (ha a megfelelő gerjesztési hullámhosszokat és szűrőrendszert alkalmazzuk), mely megjelenik a dot plot-on. Az egyik leggyakrabban használt fluoreszcens festék a propidium-jodid (PI), ami a DNS nagy árkába kötődik, így a DNS mennyiség mérhetôvé vállik (a PI intenzitása egyenesen arányos a DNS mennyiségével), ami hasznos a sejtciklus fázisainak meghatározásában (Crowley, Chojnowski és Waterhouse, 2016).

1. ábra: Egy S fázisú sejt dot plot-ja. Az x-tengelyen az elöre szórás (FSC-A) és azy-tengelyen az. oldalra szórás (SSC-A) látható. (forrás: a Szerzó)

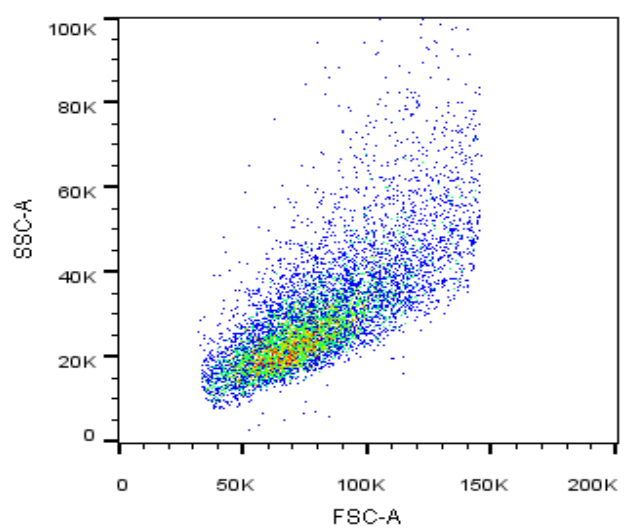




\section{Patch-clamp}

A legfontosabb eszköz a celluláris elektrofiziológiában a patch-clamp. Ezzel azt az áramot tudjuk detektálni, ami a sejtmembránon keresztül folyik. Ehhez pedig két elektródára van szükség (egy belső elektródára, ami az üvegpipettában van a belső oldatban és egy külső elektródára, ami a sejten kívül van a külső oldatban). Létezik feszültség-zár (voltage-clamp) és áram-zár (current-clamp) üzemmód. Az előbbi segítségével meg tudjuk határozni a sejtmembránon keresztülfolyó áramot úgy, hogy a mérőfejjel változtatni és kontrollálni tudjuk a membrán két oldala között lévő feszültséget. A másik üzemmódnál a mérőfejjel a sejtmembránon átfolyó áramot tudjuk befolyásolni és emiatt mérhetővé vállik a bekövetkező feszültségváltozás. Van pár konfiguráció, amit érdemes megemlítenünk. Az első a cellattached konfiguráció, mikor a pipetta a membrán felszínéhez ér és az alkalmazott szívással gigasealt $(R=1 G \Omega)$ érünk el. Ezzel a módszerrel az egyéni csatorna aktivitását lehet vizsgálni. Ha azonban több csatornát szeretnénk szimultán detektálni, akkor hozzáférést kell szerezni a cytoplasmához, ami a gigaseal utáni membrán megszakításával érhető el. Ez a whole-cell (teljes-sejtes) konfiguráció. A farmakológiai tanulmányokhoz az inside-out és outside-out technikák lehetnek szükségesek. Az előbbi a cell-attached, az utóbbi pedig a whole-cell konfigurációból érhető el a pipetta sejttől való elhúzásával (Sakmann és Neher, 1984). Ebben a kísérletsorozatban a teljes-sejtes konfigurációt használtuk mind a biofizikai paraméterek (csúcsáram és felületegységre normált áramsűrűség) és a BK béta alegységek farmakológiai teszteléséhez is.

Elönyök: Valós időben tudjuk észlelni az adott múködő ioncsatornákat és nem csak a csatorna proteineket, mint Western blottal. Hátrányok: a patch-clamppel az összes jelenlévő áramot detektáljuk és nemcsak azt, amire szükségünk van (persze ez többnyire kivédhető csatorna gátlószerek alkalmazásával és a külső/belső oldatok összetételének változtatásával).

\section{Eljárás}

\section{Sejtszinkronizáció}

Először szinkronizáltuk az U-87 glioblasztóma sejteket. Az $\mathrm{M}$ fázishoz 4 $\mu \mathrm{g} / \mathrm{ml}$ kolhicint, az S fázishoz $4 \mu \mathrm{g} / \mathrm{ml}$ aphidicolint és a G0/G1 fázis eléréséhez szérummentes DMEM-et használtunk. A kezelések után a sejtek 24 órán keresztül inkubálódtak $37{ }^{\circ} \mathrm{C}-\mathrm{on}$. (Ez a lépés minden egyes patch-clamp mérés és áramlási citometria rekordálás előtt megtörtént.)

\section{Áramlási citometria}

A szinkronizálás sikerességét PI-os sejtciklus áramlási citometriával ellenőriztük. A DNS mennyiség kétfajta szűrőrendszerrel volt mérve: Yellow-A-t használtunk a kontoll, az éheztetett és a kolhicinnel kezelt populációknál (gerjesztési szűrő: $532 \mathrm{~nm} /$ emissziós szűrő: 564 606 nm) és PE-Texas Red-A-t használtunk az aphidicolinnal kezelt csoportnál (gerjesztési szűrő: 561 nm/emissziós szű- 
rő: $610-620 \mathrm{~nm})$. Mindkettő szett alkalmas a PI intenzitás vizsgálatához ugyanis a PI excitációs maximuma $535 \mathrm{~nm}$, emissziós maximuma pedig $617 \mathrm{~nm}$. (Ez a lépés egyszer történt meg az első kezelések után). A kapott adatokat FlowJo VX nevű program segítségével értékeltük ki.

\section{Patch-clamp}

A tumorsejtek biofizikai paraméterinek vizsgálatához használt oldatok a következők voltak. Külső oldatként nátrium-alapú oldatot (145 mM NaCl, 5,5 mM glükóz, 5 $\mathrm{mM} \mathrm{KCl}, 2,5 \mathrm{mM} \mathrm{CaCl}_{2}, 1 \mathrm{mM} \mathrm{MgCl} 2,10$ $\mathrm{mM}$ HEPES, $\mathrm{pH}=7,35)$ és belső oldatként KF-alapú oldatot használtunk (140 mM KF, 11 mM EGTA, 10 mM HEPES, $2 \mathrm{mM} \mathrm{MgCl}, 1 \mathrm{mM} \mathrm{CaCl} 2, \mathrm{pH}=7,23)$.
Protokollként a sejteket $-100 \mathrm{mV}$-os tartófeszültségről a $-80 \mathrm{mV}-+140 \mathrm{mV}$ tartományban depolarizáltam $+20 \mathrm{mV}$-os lépésekben 200 ms hosszúságú impulzusokat 5 s-ként alkalmazva (lásd: 2. ábra).

$\mathrm{Az}$ így kapott I-V (áram-feszültség) görbékkel a sejtek csúcsáramát és a kiszámított, felületegységre normált áramsűrűségét hasonlítottam össze a különböző populációk között ( $\mathrm{n}=10$ sejt mind a négy csoportból) one way ANOVA statisztikai próbát alkalmazva. Különbség esetén post-hoc analízisként Tukey's Multiple Comparison-t használtam a csoportok összehasonlítására. Az egyes csoportok közötti statisztikai különbségek $\mathrm{p}<0.05$ szint esetében tekinthetők szignifikánsnak.

2. ábra: A bal felsöpanelen látható az I-V feszültség-protokoll, a jobb felsö panelen pedig a protokollal egy $M$ fázisú sejten mért áramgörbék. A bal alsó panelen a farmakológiai mérésekhez használt feszültség-protokollt, a jobb alsó panelen a protokollal egy $M$ fázisú sejten kapott áramgörbéket tüntettem fel (forrás: a Szerző).
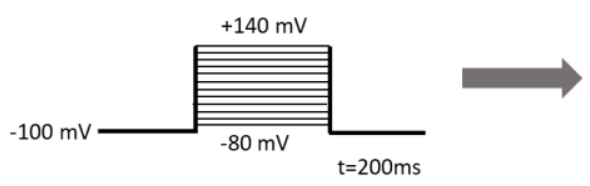

$\mathrm{t}=200 \mathrm{~ms}$

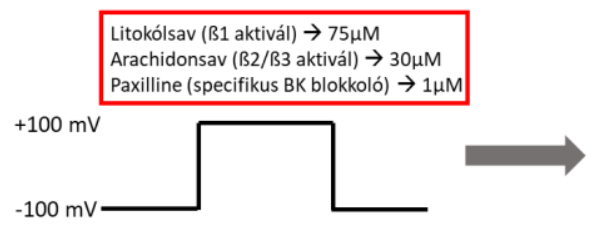

$\mathrm{t}=200 \mathrm{~ms}$
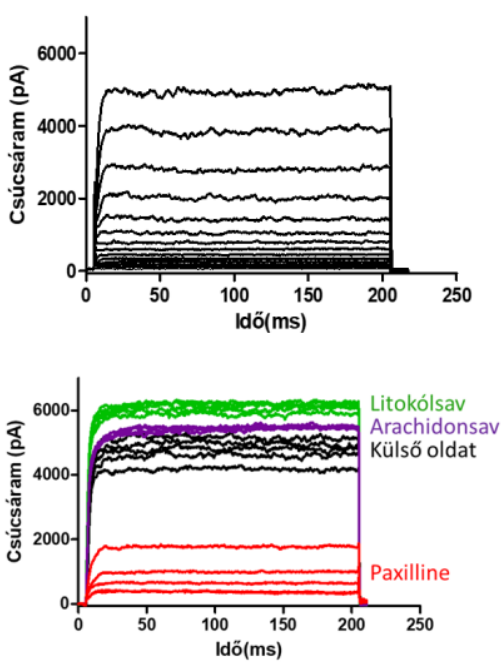
A BK csatorna béta alegység mintázatának feltérképezéséhez használt oldatok: belső oldat (145 mM K-aszpartát, $10 \mathrm{mM}$ EGTA, $10 \mathrm{mM}$ HEPES, $2 \mathrm{mM} \mathrm{MgCl}_{2}$, 8,5 $\left.\mathrm{mM} \mathrm{CaCl}_{2}, \mathrm{pH}=7,2\right)$, külső oldat (145 mM Na-aszpartát, $10 \mathrm{mM}$ HEPES, 5,5 $\mathrm{mM}$ glükóz, $5 \mathrm{mM} \mathrm{KCl,} \mathrm{2,5} \mathrm{mM} \mathrm{CaCl}_{2}, 1$ $\mathrm{mM} \mathrm{MgCl}$, $\mathrm{pH}=7,4)$. Ebben a protokollban is $-100 \mathrm{mV}$-os tartófesztültséget alkalmaztunk, de itt a sejteket mindig +100 mV-ra depolarizáltam 200 ms időtartamra 5s-ként (lásd: 2. ábra). Így vizsgáltuk a BK csatornára specifikusan ható anyagokat, mint a litokólsavat $(75 \mu \mathrm{M})$, ami 31 alegység jelenléte esetében aktiválja a csatornát, az arachidonsavat $(30 \mu \mathrm{M})$, ami $\beta 2 / \beta 3$ koexpresszió esetében növeli meg a csúcsáramot, valamint alkalmaztuk a $\mathrm{BK}$ csatorna specifikus gátlószerét a Paxilline$\mathrm{t}(1 \mu \mathrm{M})$. Mind a négy populációból lemértünk $n=10$ sejtet, majd minden sejtnél az adott farmakon hatására kapott csúcsáramokat átlagoluk és normáltuk a külső oldatban mért csúcsáramhoz képest.

Az adott szer hatását egyoldalú egymintás t-próba alkalmazásával teszteltük, valamint a béta alegységek sejtciklus függő változását egytényezôs varianciaanalízissel (one way ANOVA) vizsgáltuk, ahol posthoc analízisként Dunnett's Multiple Comparison tesztet végeztünk el, ami a kezelést kapott csoportokat hasonlította össze a kezeletlen kontroll csoporttal $(\mathrm{p}<0,05)$.
A grafikonok készítéséhez GraphPad Prism nevű programot használtam.

\section{Eredmények}

\section{A szinkeronizálás sikeressége}

Az áramlási citométerrel kapott adatok alapján a kontroll, kezeletlen U-87 sejtpopuláció a következőképpen oszlott meg: 82,7\% G0 fázisban, 7,4\% $\mathrm{S}$ fázisban és 9,8\% M fázisban volt jelen. A $4 \mu \mathrm{g} / \mathrm{ml}$ kolhicinnel kezelt populációnál a sejtek 58\%-a volt G0 fázisban és 8,6\%-a S fázisban, míg az M fázisú sejtek aránya megnőtt 33,4\%-ra. Ez a kontroll/kezeletlen sejtekhez képest 3,4-szeres emelkedést jelent az M fázisban.

$\mathrm{Az}$ éheztetéses technikával (szérummentes DMEM) kezelt sejteknél is meggyőzőek voltak az eredmények: a tumorsejtek 90,8\%-a volt G0 fázisban (5,4\% S fázisban, valamint 3,8\% M fázisban volt jelen), ami alapján az éheztetéses technika a G0 sejtek arányát több mint 8\%-kal növelte meg.

A $4 \mu \mathrm{g} / \mathrm{ml}$ aphidicolinnal kezelt U-87eknél az áramlási citometria eredménye alapján a sejtek 77\%-a G0 fázisban maradt. Az S fázisú sejtek 16,8\%-ban és az M fázisú sejtek 13,6\%-ban voltak jelen, tehát a kezeletlen populációhoz képest az $\mathrm{S}$ fázisban lévő tumorsejtek aránya a 2,2szeresére emelkedett (lásd: 1. táblázat és 3. ábra). 
3. ábra: Bal oldalon látható a kontroll, éheztetett (szérummentes DMEM) és a kolbicinnel kezelt sejtek hisztogramja. Jobb oldalt az aphidicolinnal kezelt sejtek eloszlása szemlélhetố. Az x-tengely a PI intenzitást, azy-tengely a sejtszámot jelöli (forrás: a Szerzó).

Kezeletlen kontroll

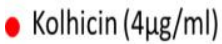

Szérummentes DMEM

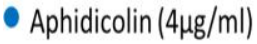
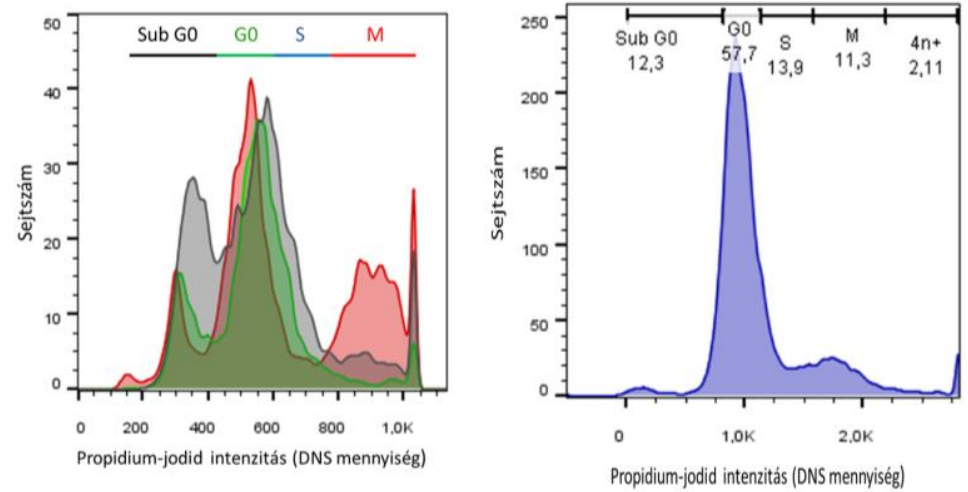

\section{Biofizikai paraméterek}

Az adatok alapján a kezelést nem kapott kontroll, az aphidicolinnal ( $\mathrm{S}$ fázis) és a szérummentes DMEM-mel (G0 fázis) kezelt populációk között sem csúcsáramban, sem áramsűrűségben nem volt megfigyelhető szignifikáns különbség ( $\mathrm{p}>0,05)$. Kivételt képeznek a G0 sejtek áramsűrüségei +120 és $+140 \mathrm{mV}$-on. Előbbi feszültségen átlagosan 59,75 $\mathrm{nA} / \mathrm{nF}$-dal, míg utóbbin 101,2 nA/nF-dal emelkedett az áramsűrűség a kontroll sejtekhez képest (lásd: 4. ábra). Mivel a csúcsáramok nem emelkedtek szignifikánsan, ez az eltérés azzal magyarázható, hogy a G0 fázisú sejtek kisebb méretűek voltak, ami az éheztetéses szinkronizáció (szérummentesség) következménye lehet. A kolhicinnel kezelt $M$ fázisú sejteknél azonban már egyéni mérések során is szembetűnő volt a csúcsáram megemelkedése. Az alábbi ábrán látható I-V görbéken a BK csatorna +60 mV-os depolarizációnál kezd nyitni. Tíz sejt adatai lapján látható, hogy az M fázisba szinkronizált sejteknek mind a csúcsárama, mind az áramsűrűsége szignifikánsan nagyobb, mint szinkronizálatlan sejteké, és a különbség már -20mV-os feszültségtôl látható $(p<0,05)$. A $+60 \mathrm{mV}$ tól $+140 \mathrm{mV}$-ig tartó intervallumban (ahol a BK csatorna aktív) a csúcsáram átlagosan 1,15 $(+60 \mathrm{mV}), 1,5(+80 \mathrm{mV}), 1,4$ $(+100 \mathrm{mV}), 1,8(+120 \mathrm{mV})$ és $2,4(+140$ $\mathrm{mV}$ ) nanoamperrel emelkedett. Az áramsűrűség ugyanebben a tartományban 36.8, 52.9, 67.3, 69 és $81.5 \mathrm{nA} / \mathrm{nF}$-al növekedett (lásd: 4. ábra). 
4. ábra: Balról-jobbra láthatóak a GO, S és $M$ fázisú sejtek csúcsárama (felül) és felületegységre normált áramsürüsége (alul). ${ }^{*} p<0,05,{ }^{* *} p<0,01,{ }^{* * *} p<0,001$ (forrás: a Szerzö)
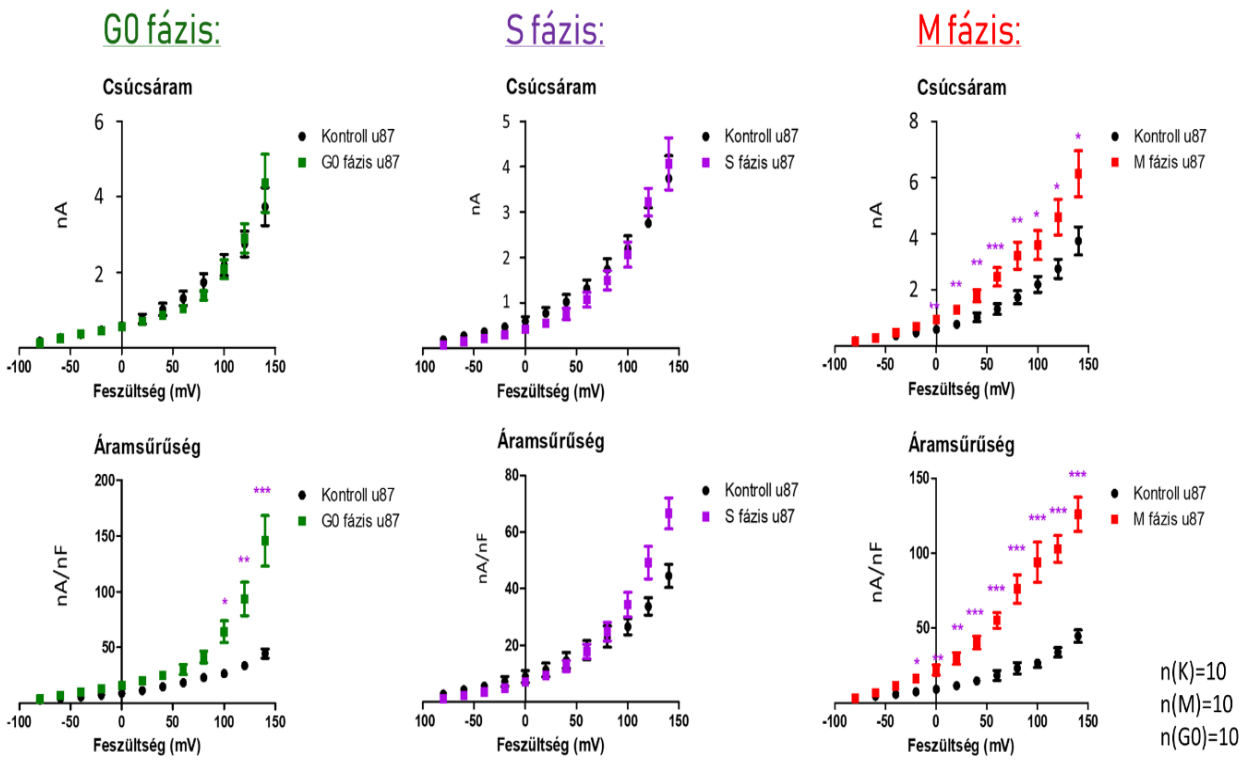

\section{Farmakológiai eredmények}

A kezeletlen kontroll sejtek csúcsárama +100 mV-os feszültségen LCA hatására átlagosan az 1,28-szorosára (SEM=0,17), míg AA jelenlétében átlagosan 1,15szörösére $(\mathrm{SEM}=0,077)$ emelkedett (az egyoldalú, egymintás t-próba eredménye szerint mindkét farmakon szignifikánsan megemelte a csúcsáramot $\mathrm{p}_{\mathrm{LCA}}=0,0021$, $\left.\mathrm{p}_{\mathrm{AA}}=0,0252\right)$.

A BK csatornára nézve gátló hatású Paxilline a kezeletlen U-87 sejtek csúcsáramát átlagosan a 0,19-szeresére csökkentette le $(\mathrm{SEM}=0,116)$. Az aphidi-colin kezelést kapó S fázisú glioblasztóma sejtek csúcsárama LCA hatására átlagosan 1,32-szeresére $(\mathrm{SEM}=0,13)$ növekedett (szignifikáns növekedés, $\mathrm{p}=0,0002$ ), AA hatására pedig a csúcsáram átlagosan nem változott jelentősen (1,02-szeres emelkedést okozott az ionáram amplitúdójában SEM=0,081). A Paxilline itt is hatott, hiszen a csúcsáramot átlagosan 0,3-szorosára csökkentette le (SEM=0,106). A szérummentes DMEM-et kapó (éheztetett) G0/G1 fázisú sejtek csúcsáramát a LCA átlagosan 1,3-szorosára (SEM=0,17), míg az AA átlagosan 1,1-szeresére (SEM= 0,09) emelte meg (mindkettő farmakon szignifikánsan hatott, $\mathrm{p}_{\mathrm{LCA}}=0,0013, \mathrm{p}_{\mathrm{AA}}=$ 0,0139). Paxilline-os perfúzió után pedig a csúcsáram átlagosan 0,17-szeresére csökkent le (SEM=0,074).

A kolhicinnel kezelt M fázisú sejtpopulációnál a csúcsáram LCA hozzáadása után átlagosan 1,1-szeresére $(\mathrm{SEM}=0,1)$ 
(szignifikáns emelkedés, $\mathrm{p}=0,0092$ ), AA hatására pedig átlagosan 0,98-szorosára változott (SEM=0,109). Paxilline adása után a gátló hatás nem bizonyult olyan effektívnek, mint a többi csoportnál, hiszen a csúcsáramot átlagosan csupán 0,4szeresére csökkentette le (SEM=0,122 lásd: 5. ábra).

5. ábra: Bal oldalt a litokólsav, jobb oldalt pedig az arachidonsav BK áramon kifejtett hatása látbató. Azy-tengelyen ábrázolt normált áram: az adott perfúzió jelenlétében mért stabil csúcsáramok átlaga a külsö oldatban mért csúcsáramok átlagára normálva. * $p<0,05, *^{*} p<0,01, * * * p<0,001$ Forrás: a Szerzố.

(ß1)

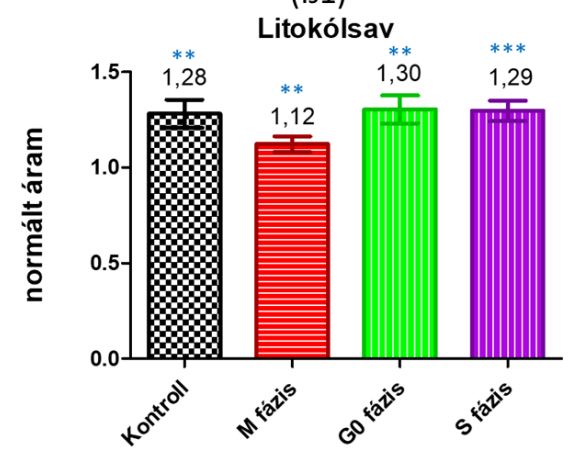

\section{Megvitatás}

Az egyutas varianciaanalízis eredménye alapján az M fázisú sejtek biofizikai paraméterei szignifikánsan eltérnek a kontroll populációtól. A G0 fázisú sejteknél látott eltérések magyarázhatóak a szérummentesség okozta sejtméret csökkenésével (lásd: 6. ábra). A farmakológiai mérések alapján a litokólsav mind a négy populációnál szignifikánsan hatott, így a ß1 alegység sejtciklustól függetlenül kifejeződik a glioblasztóma sejtekben. Az arachidonsav az egyoldalú, egymintás t-próba alapján csak a kontroll és a G0 fázisú populációk-

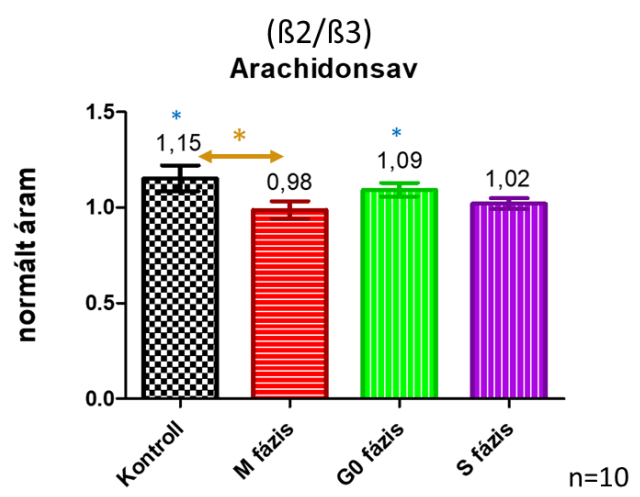

nál hatott szignifikánsan, ami azt jelenti, hogy itt jelen lehet $32 / \beta 3$ koexpresszió. Ezen adatok alapján azonban az M fázisú sejtek biofizikai paramétereinek eltérése nem magyarázható a béta alegységek kifejeződésének megváltozásával, tehát az eltérést egy ismeretlen ionáram adja. Ez az áram jelenlegi feltételezéseink szerint kloridáram lehet, mivel a farmakológiai mérések csak a kloridszegény oldatok alkalmazásával voltak kivitelezhetőek és az is látható, hogy a paxilline az M fázisú sejteknél kevésbé fejtette ki a hatását (lásd: 7 . ábra). 
6. ábra: A kontroll és GO fázisú sejtek kapacitása látható. A kapacitás egyenesen arányos a sejt felületének nagyságával (forrás: a Szurzố).

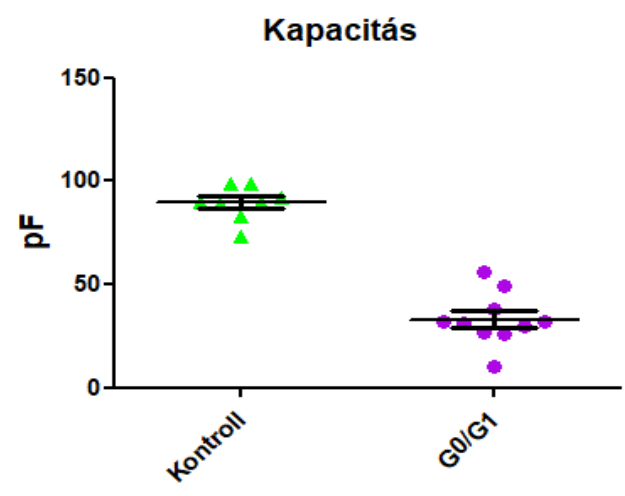

7. ábra: A paxilline hatása látható a különböző populációknál (forrás: a Szerzố).

Paxilline

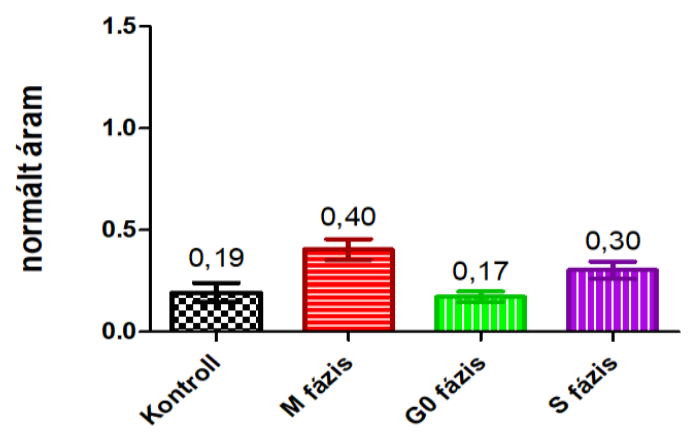

\section{Korlátozások}

A minta hátránya: Az U-87 MG sejtek a több mutáción átmentek már a megközelítőleg 50 év alatt, ezért genetikailag eltérhetnek a glioblasztóma sejtektől, azonban nincs információnk arról, hogy lenne különbség az ioncsatorna expresszióban a sejtvonal és a glioblasztóma sejtek közt.
A mintavétel korlátatai: Habár a szinkronizáció megemelte az adott fázisban lévő sejtek arányát és igyekeztünk az adott fázisra jellemző méretű és morfológiájú sejteket kiválasztani az elektrofiziológiai mérésekhez, a 100\%-os mintavételi siker nem mondható ki. 
Patch-clamp korlátok: A patch-clamppel az összes jelenlévő áramot detektáljuk és nemcsak azt, amire szükségünk van.

Farmakonok egyéb hatásai: A használt farmakonok közül a litokólsavnak és a paxilinnek BK csatorna specifikus hatása van. Azonban az arachidonsavnak a B2/B3 koexpresszió jelenlétében történő BK csatorna aktiváció mellett ismert a protoncsatorna aktiváló hatása is.

\section{Konklúziók}

Az áramlási citométerrel kapott adatok alapján a szinkronizáció sikeresnek tekinthetô mind a G0, M és S fázisba, ami megnövelte a valószínűségét annak, hogy az elektrofiziológiai mérések során adott fázisú sejtről nyerjünk információt.

A patch-clamp eredmények alapján a sikeres szinkronizációt követően az M fázisban lévő tumorsejtek csúcsáram és felületegységre normált áramsűrűsége is szignifikánsan nagyobbnak bizonyult a kezeletlen kontroll populációhoz képest. Ezzel ellentétben az aphidicolinnal kezelt $S$ fázisú sejtek és az éheztetéses technikával szinkronizált G0 fázisú sejtek nem mutattak eltérést sem csúcsáramban, sem áramsűrűségben a kontroll popu-lációtól.

A farmakológiai mérések alapján mind a négy tesztelt populációnál hasonló eredmények születtek, miszerint a litokólsav jelentősen megemelte a sejtek csúcsáramát, ellentétben az arachidonsavval. Ezzel az információval kijelenthetjük, hogy az U-87 MG sejtek mind a G0, S és M fázis- ban kifejezik a BK B1 alegységet, továbbá valószínűsíthetjük, hogy a tumor-sejtek expresszálják a $\beta 2$ és/vagy a $B 3$ alegységet. Így az eredmények alapján nincs különbség a BK béta alegység min-tázatban a sejtciklus függvényében, ami azt jelenti, hogy egy BK béta alegység mintázatra specifikus gátlószerrel sejtcik-lus független gátlást lehet elérni.

A jövőben ki kell deríteni, hogy az M fázisú sejteknél mi okozta a tapasztalt szignifikáns eltéréseket. Egyik irány lehetne a tumorsejteken a klorid áram vizsgálata, mivel ismert, hogy a calcium-függő kálium csatornákon kívül a klorid csatornák is fontos szerepet játszanak a sejtproliferációban, valamint a $\mathrm{ClC}-3 \quad \mathrm{H}^{+} / \mathrm{Cl}^{-}$ antiporter is bizonyítottan hozzá-járul a glio-blasztóma invazivitásához.

Ezen felül érdemes megemlíteni, hogy a farmakológiai mérések a külső és belső oldat cseréje előtt (kloridszegény oldatra váltás) kivitelezhetetlenek voltak, ami szintén jele a klorid áramnak. Az előbbin kívül fontos még kideríteni, hogy a farmakológiai mérések során az arachidonsav a B2/B3 koexpresszió hiányában volt-e kevésbé hatásos a litokólsavnál. Ennek érdekében meg kell vizsgálni a kontroll és szinkronizált tumorsejtek fehérje expresszióját Western blot technikát alkalmazva.

\section{Irodalom}

Allen M, Bjerke M, Edlund H, Nelander S and Westermark B. (2016): Origin of the U87MG glioma cell line: Good news and bad news. Sci Transl Med. 
2016; 8 (354): $354 \mathrm{re} 3$ doi: $\underline{10.1126 / \text { scitransl med.aaf6853 }}$

Burzynski SR, Lewy RI, Weaver R, Janicki

T, Jurida G, Khan M, et al (2004):

Long-term survival and complete response of a patient with recurrent diffuse intrinsic brain stem glioblastoma multiforme. Integr Cancer Ther. 2004; 3 (3) : 257-61 doi: $\underline{10.1177 / 1534735404267748}$

Crowley L.C., Chojnowski G., and Waterhouse N.J. (2016): Measuring the DNA Content of Cells in Apoptosis and at Different Cell-Cycle Stages by Propidium Iodide Staining and Flow Cytometry. Cold Spring Harb Protoc.2016(10) doi: 10.1101/pdb. prot087247

Darzynkiewicz Z., Halicka H.D., Zhao H. and Podhorecka M. (2011): Cell synchronization by inhibitors of DNA replication induces replication stress and DNA damage response: analysis by flow cytometry. Methods Mol Biol. 2011;761:85-96 doi: 10.1007/978-161779-182-6 6

Encyclopedia of life sciences. London, New York: John Wiley \& Sons; 2005. 20 volumes

Huber SM, Butz L, Stegen B, Klumpp D, Braun N, Ruth P, et al. (2013): Ionizing radiation, ion transports, and radioresistance of cancer cells. Front Physiol. 2013; 4: 212 doi: 10.3389/ fphys.2013.00212

Joshi AD, Parsons DW, Velculescu VE,

Riggins GJ. (0211): Sodium ion channel mutations in glioblastoma patients correlate with shorter survival. Mol Cancer. 2011; 10: 17 doi: 10.1186/1476-4598-10-17

Kumar V., Abul K. Abbas A.K., Fausto N. and Mitchell R. N. (2007): Robbins Basic Pathology. 8th edition. ed. London: Saunders.

Lee US and Cui J. (2010): BK channel activation: structural and functional insights. Trends Neurosci. 2010; 33 (9): 415-23 doi: 10.1016/j.tins.2010.06.004

Li Q and Yan J. (2016): Modulation of BK Channel Function by Auxiliary Beta and Gamma Subunits. Int Rev Neurobiol. 2016; 128: 51-90 doi: 10.1016/bs.irn.2016.03.015

Lloyd DR, Holmes P, Jackson LP, Emery AN and Al-Rubeai M. (2000): Relationship between cell size, cell cycle and specific recombinant protein productivity. Cytotechnology. 2000; 34 (12):59-70 doi: 10.1023/A:1008103730 $\underline{027}$

McFerrin MB and Sontheimer H. (2006): A role for ion channels in glioma cell invasion. Neuron Glia Biol. 2006; 2 (1): 39-49 doi: $10.1017 /$ S17440925X06000 $\underline{044}$

Poulsen, AN, Wulf, H, Hay-Schmidt, A, Jansen-Olesen, I, Olesen, J and Klaerke, DA. (2009): Differential expression of $\mathrm{BK}$ channel isoforms and beta-subunits in rat neuro-vascular tissues. Biochim Biophys Acta. 2009;1788(2):380-9 doi: 10.1016/j. bbamem.2008.10.001

Rosa P, Sforna L, Carlomagno S, Mangino G, Miscusi M, Pessia M, et 
al. (2017): Overexpression of LargeConductance Calcium-Activated Potassium Channels in Human Glioblastoma Stem-Like Cells and Their Role in Cell Migration. J Cell Physiol. 2017; 232 (9) : 2478-88 doi: 10.1002/jcp. 25592

Sakmann B. and Neher E. (1984): Patch clamp techniques for studying ionic channels in excitable membranes. Annu Rev Physiol. 1984; 46: 455-72 doi: 10.1146/annurev.ph.46.030184.00232 $\underline{3}$

Steinle M, Palme D, Misovic M, Rudner J, Dittmann K, Lukowski R, et al. (2011): Ionizing radiation induces migration of glioblastoma cells by activating $\mathrm{BK} \mathrm{K}(+)$ channels. Radiother Oncol. 2011; 101 (1): 122-6 doi: 10.1016/j.radonc.2011.05.069
Taylor E.W. (1965): The Mechanism of Colchicine Inhibition of Mitosis. I. Kinetics of Inhibition and the Binding of H3-Colchicine. J Cell Biol. 1965; 25 : SUPPL:145-60 doi: 10.1083/jcb.25.1. $\underline{145}$

Wang B, Xie J, He HY, Huang EW, Cao QH, Luo L, et al. (2017): Suppression of CLC-3 chloride channel reduces the aggressiveness of glioma through inhibiting nuclear factor-kappaB pathway. Oncotarget. 2017; 8 (38): 63788-98 doi: 10.18632/oncotarget. $\underline{19093}$

Yan L. and Tao M. (2007): Effects of serum starvation and contact inhibition on the cell cycle G0 synchronization of the human embryonic lung fibroblast. Wei Sheng Yan Jiu. 2007;36(3):275-8 